\title{
Cell Cycle Protein
}

National Cancer Institute

\section{Source}

National Cancer Institute. Cell Cycle Protein. NCI Thesaurus. Code C17761.

Proteins involved in the process of cell division. Numerous proteins of different functionality and type are involved in this process. 